\title{
Fecal indicator bacteria in tropical beach sand: baseline findings from Port Dickson coastline, Strait of Malacca (Malaysia)
}

\begin{abstract}
This pilot study aims to assess Escherichia coli (E. coli) contamination and its perceived health risks among beachgoers in ten tropical beach sands along Port Dickson coastline (Malaysia). This study also aims to determine the relationship between perceived health symptoms and tropical beach sand exposure behavior. The concentration of E. coli in tropical beach sand ranged from $60 \mathrm{cfu} / 100 \mathrm{~g}$ to $4113 \mathrm{cfu} / 100 \mathrm{~g}$. E. coli contamination was the highest at Tanjung Gemuk $(4113 \pm 30 \mathrm{cfu} / 100 \mathrm{~g})$ and the lowest at Tanjung Tuan $(60 \pm 15 \mathrm{cfu} / 100 \mathrm{~g})$; the high level of contamination could be due to the location of the former at the sewage outlet of nearby hotels. Skin symptoms were the most predominant among the health symptoms indicated by beachgoers. Exposure duration was significantly correlated with the perceived health symptoms among beachgoers in the beaches studied.
\end{abstract}

Keyword: Tropical beach sand; Escherichia coli; Exposure; Health symptoms 